\title{
A Different Way to Conclude: Liberation Day
}

Today $^{94}$ I would like to anticipate somehow the 'great liberation' of next Friday, which will take place on the 15th of May and which is a much awaited event by the majority of the persons in self-isolation at home.

We shall approach this issue from the perspective of an ethics that we have called the 'ethics of the pandemic' and that we can already correlate with an ethics of the educational system's migration to the virtual, of the isolation from the other, of the assumed deconstruction of freedom etc. The challenges that the 'great liberation' will bring starting with the $15^{\text {th }}$ of May - and which happened already in countries as Germany, the Czech Republic, France - after the period when the freedom of circulation has been restrained at a necessary minimum and circulation needed to be well declared - we speak in a non-metaphorical manner when we say well declared, referring to the affidavit for walking the dog or providing food, an unprecedented situation -, will target the re-learning of freedom. The first thing we shall have to (re)learn after this pandemic of stillness will be to acquire mobilty, as we learned to be remote, although not many of us learned to be internalized, to be retreated in the company of our own self, as we were content to be retreated from a formal externality. We have opposed to the physical externalization by using the virtual one, which has immunity to the Coronavirus

\footnotetext{
94 The lecture has been sustained on the $7^{\text {th }}$ May 2020, within the Thursday Meetings with Biotehics and Applied Bioethics, developed within the Applied Ethics and Practical Philosophy Circle 'Ekpyrosis'.
} 
pandemic, but which is much affected by the infodemics of 'fake news' and 'virtual hate'.

So, as I was saying, we shall have to circulate, but this time not only to circulate freely, but to circulate in full awareness, to be aware to the fact that we have gained a degree of liberty and, just as the founding fathers of the USA asserted, freedom is always at a generation distance from us - which means that its loss or gain depends on us. We should also be at a pandemic distance of the understanding of freedom and maybe the most important lesson that this pandemic transmits us is that the freedom can be retreated from us due to a tiny, little thing, of a few microns, that we cannot even see through the microscope and surely not with the free eye, and which can do us a lot of harm at the individual level, and can even kill us, or throw us into unemployment, be it technical or not, into economic crisis, lead us to the closing of the schools and toward an online educational system.

So this 'tiny thing or being' - the virus - is in-between thing and being, only partially considered a living being because it does not have its own capacity to reproduce and it needs a host for that - , can make us many difficulties, but it also brings to us a lesson, a lesson of freedom. First of all, a lesson of the social, political and, last but not least, of ethical liberty. This liberty is correlated with responsibility. When we receive indications to stay at home we are demanded, in fact, to be responsible for our health status as well as for the others, who could be affected by our lack of responsibility. Now, after the $15^{\text {th }}$ of May, we receive a plus of liberty, the ability to get out of the house without reporting it to anybody and especially, without declaring in writing the purpose and duration of the travel. Why am I saying that this is an important element even from an ethical point of view? Because it makes us become even more responsible. By the time we were obliged to declare each travel, rather to ourselves than in front of the representatives of 
the state's institutions, we were forced to be aware of our intentions and if we had taken into consideration the legal demands, we had to write down on paper with precision what purposes we had, why did we travel, where, for how long and so on, and all these had to fill in one of the six reasons considerate to be legitimate for us to leave our homes. When we receive this freedom of travelling with no affidavit we shall have to be even more aware of our actions intentions and be responsible of them. The relaxation of the measures of social distancing can be regarded as a 'gift' that the ones responsible with the health policies make to citizens, but this is not true. We should all ask ourselves if freedom is or is not a gift.

Do we have the right to freedom? Is it given to us as a gift? Certainly, freedom is also an invitation to responsibility. When we can move freely, we can do a lot of good, but also even more bad than good. The choice is up to us most of the times. To speak only in the context of this pandemic, that means we can travel, visit the museums, go into libraries, practice individual sports, hitch-hike, as all of these were promised to us as des-limitations after the $15^{\text {th }}$ of May. But we can also do harm if we do not maintain physical distance, social-physical or whatever it will be, we can become infected with this virus, we can pass it along, by this contributing to the infection of other persons, even unintentionally. Because, to respond partially to the question previously formulated, we should understand the ethical positions that circumscribe this question, either by emphasizing the nature of freedom as a gift or the one of freedom as a right.

In the religious approach, freedom is a gift from God, it is called free will and somehow represents a sacrament, a mystery, if we were to interpret the biblical myth of the Genesis - the one with Adam and Eve who were in Paradise and who were allowed to pick up any fruit from any tree, less the one pertaining to the knowledge of good and evil and this 
precisely because Adam and Eve had this gift of freedom from the very beginning. They have chosen, at Eve's urge to Adam, inspired by the biblical snake, to disobey the divine command and to taste from the fruits that brought to them the knowledge of good and evil. Here, metaphorically, we could say that we were free when we did not know about the good and the evil. The knowledge of good and evil introduces, in fact, the un-liberty. Why? Because concomitantly with the knowledge of good and evil, appears the responsibility. If one can taste from any tree without knowing, without seeing if it is something good, something bad, that is, being in the natural status of the human being, then we cannot be made guilty for the consequences of our deeds, just as a tiger is not responsible for the harm it causes but is not aware of, this being its natural instinct, for which it is, still, hunted down, though.

So, before knowing the good and the evil, responsibility does not appear, but the free will appears right when we know the good and the bad, precisely when we have to make choices. An ethical choice imposes freedom as well, but also the responsibility for what we choose. Man was not submitted to error before biting from that apple, because to be wrong means knowing the evil and recognizing that you are faulty. Adam and Eve did not know that contravening the divine interdiction is bad, because they did not have this knowledge yet, the choice cannot be connected to a rotted nature or a nature submitted to error; we are submitted to error right after we have chosen, along with our Adamic ancestors, to know the good and the evil. From that moment on, yet, we are condemned to fall from the Eden of innocence on the earth of wickedness, the Bible tells us, but in fact, on the damned earth of hard labour, because when we know the good and the evil, we toil to our spiritual evolution, to our completion, we also toil to be free tomorrow or after the date of May, $15^{\text {th }}$, if you want, we toil to bring our lives closer to the primordial Eden. When we are 
children, we are somehow in the Eden, isn't it? Because we do not have an awareness of the good and evil. When we appropriate the moral norms, this awareness of the good and the evil appears. And Eden hides within us further on, until we find it again, we find ourselves again, we consciously find our innocence. But regained innocence is no longer of the child who does not know, but of the Christ who knows and sacrifices Himself. That consciousness of God's Kingdom, of Heaven, is regained when you crucify your own ego, that desire to be you the one who chooses between good and bad, and maybe this is what we should think about when we speak of Adam and Eve and the ancestral sin, to not confuse knowledge itself with the knowledge of the good and evil.

Yi-jing one of the fundamental books of Chinese wisdom, -Book of Changes or Classic of Changes ${ }^{95}$ (2015) -, shows that when people said that something is good, the bad appeared in the world. It is only at the moment when we make the clear distinction between what is right or wrong, that we talk of a separation and we automatically live in duality, suspended between good and bad. It is a great difference between saying that something is painful or pleasant and saying that something is good and bad. Painful, and, respectively, pleasant, are interior moods that the contact with the objective reality produces to us. Good and bad are moods that we project on the exterior reality and say: this is good, this is not good, but we are the ones who try to arbitrate what is perfect in nature and what is not. It is true that we shall say: death is bad - but it depends for whom? Pain is bad - and, again, it depends for whom? Death is bad at the moment when it separates me from the world, from the loved ones, from my life, from my goods, from my habits. Yet, death is also good because future generations will have a place on earth. If all of us would be immortal, other people could not be born because

\footnotetext{
${ }^{95}$ In Romanian: Cartea prefacerilor.
} 
there would be no more place; and voices already exist - which are crucified by public opinion - who signal the fact that the earth can no longer sustain a much greater number of people, so a continuous growth of the population is no longer sustainable because we have already destroyed the ecological resources of the planet, by consuming in half a year the resources that the earth has the capacity to regenerate in a whole year.

Good and bad are related to the person, and, thus, the two concepts become a social construction. When we build the good and the bad, we live in a virtual world, in a non-etic world, a world to which we add significations to external reality. We have debated, in a previous lecture, the movie The Englishman who went up a bill but came down a mountain (Monger, 1995), that presents a situation from Wales at the beginning of the XXth century, when mappings of Great Britain's geographical areas were realized, for strategic reasons. The inhabitants of a certain region were very proud of the fact that they are mountaineers, that they lived in the mountains, which made them different from other British people. A team of cartographers came to measure the height of the landform where the community was situated, and finds out that it is a hill and not a mountain. Who is in a position to say that a geographical form is a hill or a mountain? This is a convention. Is it good for a geographical form to be a hill? Is it better for it to be a mountain? For those mountain men, that geographical form was a mountain and could not be anything else, a hill wouldn't have been a good thing. But why? Would this in any way discomfort the citizens? No! Their projection on their own identity demanded that the geographical form be a mountain. And they transformed it into a mountain! They brought enough soil to erect the landmark and thus, the British cartographer, when retaking the measurements, found that it became a mountain, as it reached the necessary height. In fact, 
it is what we do with our free will that matters: we construct socially by saying: 'this is good and this is bad'. This good and this evil, the knowing of them represents, in fact, our freedom from a social, political and ethical point of view. Such a freedom is a gift because it transforms us from parts of the immediate world into parts of the world that is connected to the noetic, the ideatic, the world of ideas and it gets us out of the immediate, allowing us the creation of an alternative world, a noetic one, that we can consider virtual.

Virtualization does not have to be looked at only in the sense of a digital reality. From this perspective, of the knowledge of good and evil, the freedom that is associated to it is at the same time a gift, a blessing, but also a curse. When God tells Adam: 'be fruitful and multiply and fill the earth and subdue it!', can we consider this a gift or a curse? It is a blessing because ruling the earth if a right that we have as beings situated in the top of the trophic chain, as self-aware beings, but it is alto a curse because this ruling is accompanied by worries, and this worry is correlative to freedom.

But let's look at the other side of the issue: is freedom a right? Then why aren't we free? In order to assume risks towards others, we must do so by having faith. Faith would be, for example, whether or not there actually is a virus that exists at the moment of this pandemic. Based on this belief, I project scenarios about the future or interpretations about the past, which prevents me from fully experiencing the present moment. In fact, we live in projections or in a virtual reality that is not 'here' and 'now' in any form. What do 'here and now' mean? Here and now I'm talking to a camera alone, here and now I know there are 16 people as the computer monitor shows me, listening to me from somewhere on the Internet, from a virtual world. I speak here and now and nothing else happens to me; I am here, I have a certain sensation in my body, a certain physical state and that's it. At the same time I'm 
not just here, I'm with you as well, with each of you tuning 'here' to a virtual ubiquity. The sensation of 'here and now' turns into a continuous 'now' because the recording will appear online and it will be available later. 'Here and now', which was a spiritual ideal for many of us, can no longer be considered in the same way as before. On the other hand, talking about the here and now means not living in projection, not thinking: 'What will my listeners say? What will those who will listen to me say in ten days or in five days?' Even me, I do not live in the 'here and now' because I am now trying to arrange my lectures during the Thursday meetings with Bioethics and Applied Ethics students. These lectures will be published as a volume and I am waiting for the moment when this volume will be published and finally be in your hands. Already my inner state of peace is disturbed by this anticipation and I should (like a wise person and not just a philosopher and a lover of wisdom) have an inner peace and affirm: this book will come out in the end, it will find the readers it deserves on the market that I also deserve and it will find its natural way. I can't function like that, I don't possess that stoic peace when I work on my book, on the contrary, I look forward to the time this book will meet you. It means that I don't live in the 'here and now'. Why? Because I have the freedom of anticipating reality.

We can also live in a sort of remembered reality, in a reality where I could have done much more during this period of the year. Instead of writing this book, I would have recorded other TV shows or other lectures and so on, or I could have written an article or do other research that might have brought in a lot more readers. But that's not really true because I don't know how many readers this book will have or how many readers another one would have had, a book of sociology or philosophy, for example.

However, it is important to live in the present in order to maximise the wisdom of the past and build the future. 
Living in the present would make us free from good and evil, according to Nietzsche (2010). If we live in the present, we cannot judge in terms of good and evil, but in terms of experience.

Another aspect of practical philosophy is this: what we do with freedom, especially now that we have to reinvent this concept beginning with May 15th. Symbolically speaking, this day is the day of freedom, and this is not because somebody, a cruel or gentle master gives us a freedom that we actually do possess. It is because one of the assets of this period is to be aware of our freedom, which is not limited by physical walls, but by the walls of one's own consciousness. We will be able to move freely when a series of these symbolic walls are relaxed. After all, these military commands are only symbolic walls which we place on ourselves, not on others, by accepting that they are for our own good and I personally agree with these measures. It is our willingness that makes these symbolic walls insurmountable. Why so? Because we enact them with power over us all, we give them sustainability. I say again that this day is a day of freedom because we can reconcile our internal and external freedom. If we do not have an inner freedom to think of, to understand the world we live in in our own way, then we will not have a real external freedom either, but only a greater possibility of movement in our physical space.

Freedom goes hand-in-hand with will. For example, I want to go to the park but the park is closed so my will is indeed free, but I can't go to the park. If instead I go to the park by chance, I can see only how beautiful the park I came to by chance is, but there is no an act of will or freedom, but simply a random event that makes me taste reality with satisfaction. Our wonderful or painful experiences, which are not the result of any choices whatsoever, are not an expression of our freedom. The type of freedom that we receive in the absence of our awareness of having autonomy or rather to 
manifest ourselves as we feel or want, is only free movement, but this is not true freedom.

This lockdown, this situation in which we are now all almost self-isolated, more or less voluntary, can be interpreted as the biggest social experiment since World War II. It can also be perceived as an involuntary one because we hope it did not have a hidden agenda designed by some researchers, which would have led inevitably to this situation. It should be a point of interest for sociologists, public policy specialists, ethicists because the lockdown undoubtedly changes many of the current society's rules of functioning. We adopted social distancing, a term later changed to physical distancing, but in reality this lockdown is a phenomenon of social distancing, in its true sense. This is because we distance ourselves from our friends, with whom we only talk virtually (if we still do so), from our relatives, those close to us or our membership groups. When we leave our house with those statements in which we have well-founded reasons to leave the shells and go in an almost social environment, we find that sociability is simulated because in stores there are transparent Plexiglas walls between the salesclerk and the client, but they are still walls. When people walk past each other, they are wearing masks. This symbolically suggests hiding, from a virus, we believe, but perhaps our subconscious translates it into hiding from the other, whether the other is affected by the virus or not. In the end it seems to be a social experiment without any researcher.

We should treat this relaxation or reopening as an experiment in the sense of understanding the mechanisms of society's functioning that made this situation of hiding possible. Why? Because we will redefine the concept of freedom. We will be able to re-learn or way to be social beings 
again, to be human, after we have all been in a voluntary or involuntary seclusion in our own inner shells. Only by leaving the Platonic cave puts us face to face with a somewhat transformed society. Maybe we won't see any effect, maybe this period of lockdown had no effect so far or maybe we'll find that we've changed. Maybe the two months and something, almost three months have been enough to turn us into good or bad. So, you see again that Adamic choice between good and evil. We will see if the experience of distancing has influenced our way of behaving in society. If the years of socialization, of communication and communion with others have left a much stronger influence, then the distancing we will gradually set aside.

We will also see how we are going to integrate this virtualization of social space, which will lead to continuous physical distancing and implicitly of social distancing. Clearly, virtual sociability is different from sociability in physical immediacy.

As for the fear of the pandemic, which is generated by the fear of death, we can be afraid all our lives. We can also hide in houses, in bunkers, possibly postponing the very moment of dying, or live and enjoy the moments of life which we have until the moment of death.

There is a quote, whose author I can't remember for the moment, and which says: "he who dies before he dies, he dies no longer after he dies." This quotation can have two possible interpretations: on the one hand, the one who lives exclusively in the anguish of death as a constant marker of his existence actually dies for the world (from which he withdraws) precisely because of the fear of death. You died the moment you renounced to live and started to withdraw from reality until the moment you lose contact with others. You are prone to a social death, in fact. On the other hand, death is symbolic for the one who dies precisely in connection to the fear of 
death, of a common, banal existence, because he consciously chooses a spiritual path of knowing himself, of knowing his own existence, a life lived for an ideal, for a purpose for which he would be ready to die. This means that he has died in connection with most of the external things that do not define him. This interpretation is synonymous with spirituality as it is correlated with the belief in the existence of the spirit in the afterlife.

Next, I would like to bring to your attention another situation: that of two scenarios about Romania which are related to this virtualization of social space and which was first approached by Adrian Năstase, when he lost the elections against Traian Băsescu.

We are really talking about two scenarios in Romania: a rural, poor Romania and an urban, modern, almost western Romania. This period of lockdown clearly confirmed that we still live in these two scenarios, but unfortunately we try to ignore one scenario about a Romania which does not have tablets, cannot do online education and does not live the phenomenon of the virtualization of social space, because it is not possible. Instead, this Romania experiences an existential enclosing in addition to the limitations we all experience as transhuman beings, but not yet posthuman ones, who lose some of their limitations.

I have frequently spoken about the limitations concerning spatiality. The pandemic man leaves his house only with a well-defined and declared purpose and duration thus, limiting his space to his own home. Suddenly, we realize that we have barriers, self-imposed walls at the door of our apartment or house, from which we escape only virtually. Now, this limitation becomes blurred and the next question arises: do 
we or don't we have the freedom of movement? We have an injunction, a restriction on our freedom of movement, in the sense that we can't go to a picnic, we can't make barbecues, we can't participate in Easter services, but we can escape virtually anywhere reality is simulated and replaced.

Now we go to the second scenario about Romania which suddenly gained another limitation because part of the population does not have access to the Internet. It seems that now everything happens there, on the Internet where these people are excluded from and this is because they cannot be in a reality that is no longer accessible to them. Why? Because it is a virtual, augmented, extended reality, towards which we are heading at a fast pace. The fact that I can now talk to you, to each of those who look at me, makes me live as a transhuman being, a noetic one, less related to one's own corporeality and for this I need a digital-like extension. I can talk to each of those who are looking at me at this moment and those who will be looking at me in the future, I can also interact with you, try to convince you or at least transmit my ideas to you and so I have a communicative act with each of you. However, I cannot do a physical action, for example, to hug or shake your hands. This is not possible as long as we are in the virtual sphere, except through our digital avatar. We will not be able to shake hands even in the immediate post-pandemic period because it is dangerous to shake hands or hug someone as we can transmit viruses. Different categories of viruses can appear on the Internet as well and virtual security will be increasingly important and this will lead to public health policies concerning our Internet account. More than this, we already have such policies and they are called GDPR policies.

Thus, we replace one public health tyranny with another one. But the second scenario about Romania is, in fact, the second world. We begin to live in two worlds that are separated by the digital barrier. There were a number of 
prophecies that placed the end of the world in 2012, and according to them, a part of humanity would have access to other dimensions (for example, 4D, 5D and so on) and the other part, which will not have access to the above-mentioned dimensions, will remain in the $3 \mathrm{D}$ reality, not being able to communicate with those whose consciousness has been expanded up to the 4D dimension. Of course, these prophecies have not been fulfilled yet. We have changed $4 \mathrm{D}$ to $4 \mathrm{G}$ and $5 \mathrm{D}$ to $5 \mathrm{G}$, and the fear of G's destroying networks and antennas, prophesized by various conspiracy theories, is directed against antennas and not against their significance - extensions of reality in non-existent dimensions. And then, we find ourselves in the second scenario about a second humanity, which remains in $3 \mathrm{D}$ (sometimes no $\mathrm{G}$ added), meaning without the smartphone needed to participate in online courses or exams. And according to existent laws, access to education, which is guaranteed by the Constitution, is denied to them because they do not have enough G's!

For the moment, we are heading towards a rise inside the virtual, towards a more or less benevolent god, who is beginning to ask for his worshipers. This god, the Almighty Internet, multiplies itself in the great social networking sites. The offerings and the rituals are not tribal-like (stones or nuts), but take the form of attention and hours spent on those sites from which we cannot move away.

Inside this virtual space, we meet both these pseudodeities and the intention of creating the so-called godlike Artificial Intelligence, accompanied by virtual omnipotence, because it can control all communication, knowledge our habits, anticipates our desires and controls the driverless cars and perhaps, the safety of nuclear equipment. It is also omniscient in the sense of containing all libraries in its own database and it can answer any question, within the limits of knowledge accumulated by humanity so far. 
This godlike Artificial Intelligence has power over our values and it demands constant offerings from us - our time, energy and thoughts. As I was saying, there are places, not only in Romania, where we are talking about the two abovementioned scenarios, that are topical all over the world, where we can actually extend the two scenarios as well - the one with access and the one without any access at all, in terms of, health, means of living or anything else which is necessary for our life.

I am totally convinced that $5 \mathrm{G}$ networks do not transmit viruses as some conspiracy theorists tend to believe. However, it surely segments our world in those with access and those without.

\section{Acknowledgement}

An initial English version of this chapter is published in the scientific journal Logos, Universality, Mentality, Education, Novelty: Philosophy and Humanistic Sciences, volume 8, no. 1, in 2020, entitled Towards an Ethics of Responsibility in Crisis Situations: The Covid-19 Pandemic.

\section{References}

Monger, C. (Director). (1995). The Englishman Who Went Up a Hill But Came Down a Mountain [Film]. Miramax Films.

Năstase, A. (2014). Cele două Românii [The two Romanias]. Niculescu.

Nietzsche, F. (2010). Dincolo de bine și de rău [Beyond good and evil]. Antet Revolution.

YI-JING - Cartea prefacerilor [YI-JING - The book of transformations]. (2015). (W. Fotescu, Trans.). Herald. 